\title{
أثر التصوف على الحياة الروحية فى الإسلام
}

\section{The impact of Sufism on the spiritual life in Islam}

$$
\text { محمود محمد عبدالفتاح الطلي }
$$

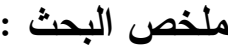

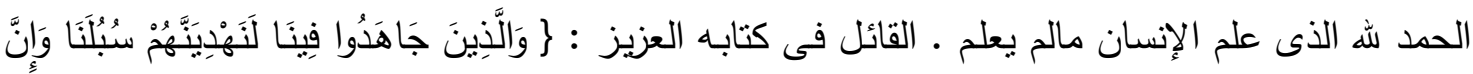

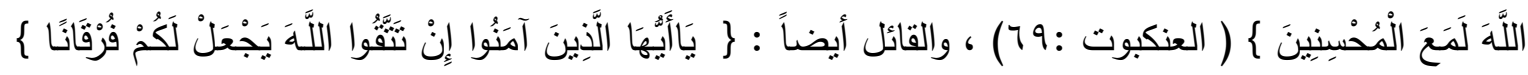

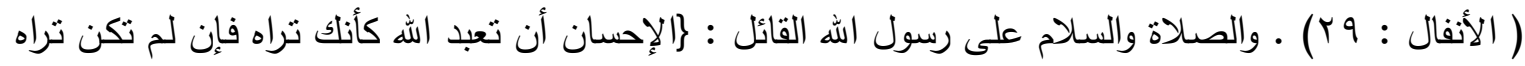
فإنه يرالك \{. وبعد : إن علم التصوف كما يراه كثير من الباحثثن يمثل الحياة الروحية في الإسـام ، ويجسد حقيقة التدين الصحيح الذى يحرك الإنسان في دائرة الفعل المسئول ، فلا حقد ، ولا عداء ، ولا حسد ، ولا بغضاء ، ولا نطاول على حقوق المخلوقين ، وهو الجسر الذى يعين الإنسان على التعايش مع أخيه الإنسان ، ولذلك وضـع لـه أصحابه قواعده وقوانينه ومنهجـه وموضـوعاته ببدايـة الإسـلام إستتناجاً من القرآن الكريم وسنة النبي الكريم صلى الله عليه وسلم واستخلاصاً من حياة الرسول صلى الله عليه وسلم وحياة أصحابه من بعده حيث يرى هؤلاء الصوفية أن الإسـلام هو الذى أرسى قواعد هذا العلم ، فعلم التصوف ليس غريباً عن

$$
\text { الإسلام ، وإنما هو من صميم الإسلام وأحد علومه الأصلية. }
$$

وعندما نتكلم عن الحياة الروحية في الإسـام فالذي يقصد بهذا العنوان هو إعطاء صورة وافية عن الحياة الروحية لرسول صلى الله عليه وسلم ، وكذلك الحياة الروحية لأصحابه من بعده رضى اله عنهم أجمعين حيث كانوا مثلاً أعلى وقدوة في زهدهم وتقتفهم وعبادتهم ، كما رسموا منهج الحياة للمسلم في دينه ودنيا ، وربطوا بين الحياة الدنيوية والحياة الآخروية بنظام استقوه من وحي الله قرآناً وسنة وأحاديث قدسية . 
فهذا بحث بعنوان ( أثر التصوف على الحياة الروحية فى الإسلام ) وقد اقتضت طبيعة هذا البحث أن يشتمل على مقدمة وتمهيد ومبحثين وخاتمة وفهرس للمصادر والمراجع · أما المقدمة : فقد اثنتملت على أسباب اختيار البحث ، وأهمية هذا البحث ، والهدف من الدراسة ، والمنهج

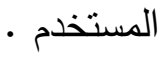
وأما التمهيد : فقد تحدثت فيه عن أهم التعريفات الواردة للبحث . وأما المباحث فقد جاءت مرنبة على النحو التالي : المبحث الأول : أثز التصوف على الجانب الروحي فى حياة النبي صلى الهه عليه وسلم . المبحث الثاني : أثر التصوف على الجانب الروحي فى حياة الصحابة رضى الله عنهم اجمعين . واما الخاتمة : فقد تضدنت أهم نتائج البحث .

لقد كان من بين أهم أسباب اختياري لهذا البحث دوافع وأسباب نجملها فيما يلى : ' أن دراسة التصوف بثكل عام من الدراسات المهمة والضرورية فى مجال الفكر الإسلامي ، ولا ريب فى ذلك فالتصوف برتقى إلى أعلى مراتب الفكر الإنساني وأرقاها ، فالمنصوف عادة لا يحمل فكراً عاديا كباقي الناس ، ولا بنظر الى الأثنياء المادية نظرة عادية ـ ولذلك كان للمنصوفة أثراً كبيراً فى الحياة الإسلامية ، بل وتعدى ذلك ليشمل الحياة الإنسانية عموماً من خلال أفكار واسهامات اولئك الدنصوفة . r_ أن هذا العصر الذى اجتاحت فيه المادة على كل شىء ، وأصبحت فيه الحياة تقوم تقويماً مادياً ضاعت فى ثناياه المثل الروحية ، ولا شك أننا الان فى وقت أحوج إلى هذه الحياة الروحية ومنلها ومعاييرها لكى تعيننا على مواجهة الحياة المادية . r- حاجة المجتمع إلى معرفة الجانب الروحي وتطبيقه فى عصر طغت عليه المادة والآلية . 
ع - إظهار أن كل ما جاء فى المنهج الصوفي من تعاليم إيمانية تعمل على الارثقاء بالنفس البشرية وتقوى

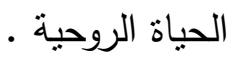
ثانياً - أهمية موضوع البحث : تتمثل أهمية هذا البحث فى كونه يتتاول :

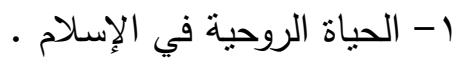

r- أثز التصوف على الحياة الروحية في حياة النبي صلى الله عليه وسلم . • _ بيان الحياة الروحية في الإسلام ع - بيان ما كان عليه صحابة رسول الله صلى الله عليه وسلم

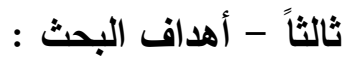
سوف تهدف الدراسة إلى : 1 - إبراز مكانة علم التصوف وأهميته ومدى حاجة الناس إليه . r- بيان أثز التصوف على الجانب الروحي في حياة النبي صلى الله عليه وسلم . ب- بيان أثز التصوف على الجانب الروحي في حياة الصحابة رضى الله عنهم أجمعين • ع - المساهمة في بيان ثمرة التصوف كنموذج للسمو الأخلاقي والمعرفي. ○_بيان أن ما جاء في التصوف من تعاليم الإسلام .

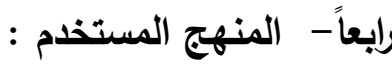

من المعلوم أن لكل باحث منهج يسير عليه ، كما أن لكل موضوع يستلزم اتخاذ منهج مناسب وملائم لله ،

$$
\text { وبما أن موضوعنا يمس طرفين : (التصوف - الإسلام) }
$$

مما يحدوا بنا أن نستخدم المنهج التحليلي المقارن مع توضيح منهجين مضمرين بالموضوع وهما : المنهج

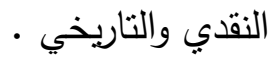




\section{التمهيد \\ التعريف بأهم المصطلحات الواردة فى عنوان البحث}

أولاً : مفهوم الجانب الروحي :

عندما نطلق مفهوم الجانب الروحي فى حياة الإنسـان لا يقصد بـه كثرة الصـلاة والصيام والتعبد وإن كان لكثرة التعبد علاقة وثيقة لبناء الجانب الروحي فى الإنسان ، ولا يقصد بالجانب الروحي حسن التعامل مـع الإنسـان والأخـاق الحسنة كالثجاعة ، والعفة ، والكرم ، وإن كان للأخلاق صلة وثثقة بالجانب الروحي ، وإنما يقصد بالجانب الروحي _ والذى يعتبر جوهرها ومضمونها ـ هي العلاقة الداخلية للمؤمن باله تعالى وتعلقه النفسي والعاطفي به تعالى من حيث الإيمان والحب والإخلاص ، وما يتعلق بهذا المعاني من خوف ورجاء وتواضع وغير ذلك (') .

ولذا يعرف الثيخ محمد مصطفى حلمي الحياة الروحية بقوله : هي الحياة التى يخضع فيها الإنسان لألوان مختلفة من مجاهدة النفس ، وتصفية القلب وتتقيته من أدران الثهوى والهوى وقطع العلائق المادية التى تفسد علاقة الإنسـان بربهـ ، وصلته بأثباهه ثم هي بعد هذا كله تأمل فى الكون ، ومشـاهدة لمبدع هذا الكون مشاهدة سبيلها الفناء عن النفس البشرية ، وقوامها البقاء فى الذات الإلهية ، والاتحاد بالحقيقة العلية والتحقق بمعرفتها معرفة يقينية لا يأتيها الثك من بين يديها ولا من خلفها (†) . نشأة الحياة الروحية : n وقد نشـأت الحيـاة الروحيـة فـى الإسـلام مـن حيـاة التقشـف والزهد والتقوى والـورع وغير ذلك مـن مظــاهر الانصراف عن الدنيا ، والإقبال على الدين بين المسلمين فى حياتهم الأولى إبان فجر الإسـام (") ، ونشـأت من اقتداء المسلمين فى جل حياتهم العامة والخاصة بالنبي صلى الله عليه وسلم بتقليده فى كل الأمور حتى

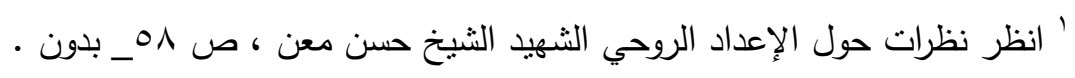

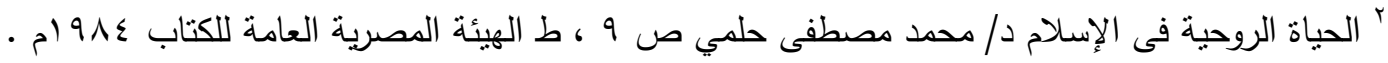

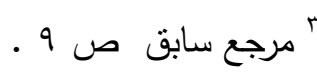


أنهم كانوا يذهبون إلى أزواجه من أمهات المؤمنين رضـى الله عنهم وأرضـاهم ليسألوهم عن حياته الخاصـة وعن أحواله التى لا يشاهدونها لبمكنهم من تطبيق ذلك كله على أنفسهم • ثم نشأت أيضـاً تلك الحياة من خـلال حياة كبار الصحابة رضـى الله عنهم أجمعين وأفعالهم وأقوالهم التى كانت مثثلً أعلى فى الزهد والتقوى والورع والتقثف ، وكيف لا يكون كذلك وهم تلاميذ مدرسـة النبوة الأولى

\section{ضرورة الحياة الروحية للإنسان :}

ويمكن تحديد ضرورة الحياة الروحية للحياة الإنسانية من خلال النواحي الآتية : أولاً : : أنها حاجة روحية كما أن الحياة الماديـة حاجة جسمية ، وكما أن الجسم إذا حرم من حاجته فـلا بـ وأن يصاب بأمراض وأضرار تضر به ، فكذلك الروح إذا حرمت من حاجتها تصاب بأمراض تضر بها ، وإن كنا هناك فرق بين هذين النوعين وطريقة الإصـابة بهما ، إلا أن إصـابة الإنسان بالأمراض الجسمية نتيجة الحرمـان من الغذاء المـادي يكون سـريعا ، وتقدر درجـة الإصـابة بدرجة الحرمان ومدة هذا الحرمـان ، أمـا بالنسبة للأمراض الروحية فإن الإنسان قد لا يشعر سريعا بضرر الحرمان كما لا يصاب بهذه الأمراض بعد الحرمان مباشرة بل قد يظهر أثر ذلك بعد مدة طويلة وقد لا يشعر المريض أن أثر ذلك هو الحرمان من الحياة الروحيـة وهذا مـا ظهر بصورة جليـة فى المجتمعات التى توغلت فى الحياة الماديـة ونسيت الحياة

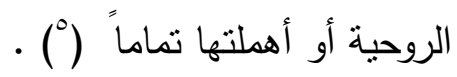

ويقول سير ريتشر لفنجستون وكيل جامعة أكسفرد : إننا نعيش جميعاً فى عالمين العالم المادي ، والعالم الروحي • والأخير هو عالم القيم ولو أننا ضحينا على العلوم أو الاقتصاديات أو الاجتماعيات أو أي شىء

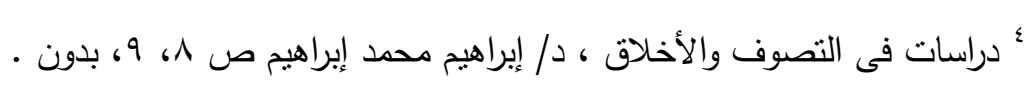

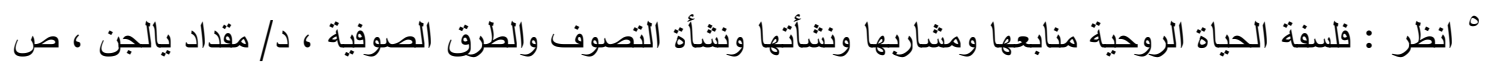
ا 
أخر لكان ذلك هو هلاكنا ، مثلنا فى ذلك مثل من يحذف الفيتامينات من طعامه ومع ذلك فإننا لا نولى هذه

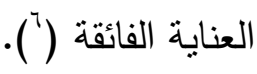

ولهذا نجد أن اله عز وجل يبين لنا أن الذى يهمل الحياة الروحية أو يُعرض عنها فإنه يعيش حياة شقية فقال

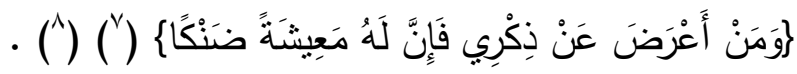
ثانياً : أن الحياة الروحية تهدف إلى صعود الإنسان بروحه واتصاله باله تعالى وهذا لا يمكن أن يتم إلا إذا ابتعد الإنسان عن الرذائل وتخلى عنها ثم تكامله بالفضائل للناس خالصة لوجه تعالى بقدر ما يقترب من الله ويزداد ارتباطه بـه ، إذ أن الناس بقدر خيراتهم تكون لهم منزلة عند الله تعالى ، وخيرة الناس تقاس بمدى زوال روح الثر عن نفسه وعمله ، وبقدر ما يقدم للناس من الأعمال الخيرية ، لهذا قال الرسول صلى الله عليه وسلم \} خير الناس أنفعهم للناس \{ (9) ، وذلك يكون بالتقدم الأخلاقي ولهذا قال رسول اله صلى الله

$$
\text { عليه وسلم \} إن من خيركم أحسنكم أخلاقا \{ ('). }
$$

وتعتبر الحياة الروحية أكتر عامل دافع للتقدم الأخلاقي وأكبر وسيلة للتقدم الاجتماعي والحضـاري ، وذلك لأن الذى يعوق التقدم الاجتماعي والحضاري هو ازدياد الجرائم المختلفة وازدياد الناس شراً مما يؤدى إلى أن يفتك بعضهم بعضاً وأن يمزق الإنسان أخاه الإنسان ، وأن يعمل لسلب خيرات الناس ، وممنلكاتهم ، وهذا الانحلال الأخلاقي من أكبر عوامل الإعاقة عند الحياة الاجتماعية وتقدمها ('). إن الحياة الروحيـة الحقيقيـة لا نكون بمجرد الانقطاع للعبادات كواجبـات تقليديـة ثم ترك المجتهـع والانعزال عنهم وقضاء الأوقات بالأوراد والذكر فى زوايا الطرق الصوفية ، بل إن الحياة الروحية الحقيقة عامل محرك

' التربية لعالم حائر كسير ريتشر لفنجستون ، ترجمة / وديع الضبع •

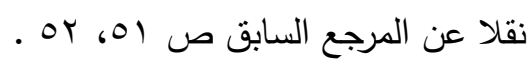

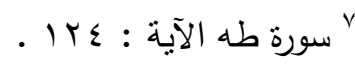

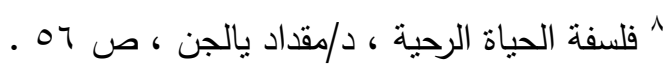

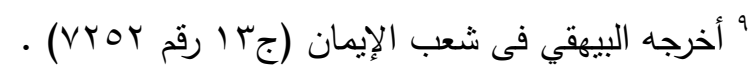

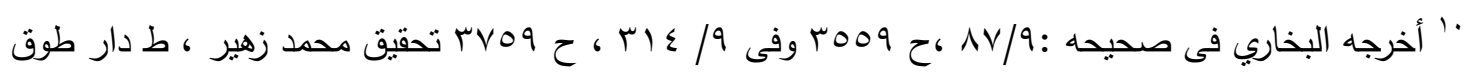

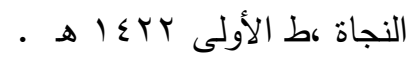

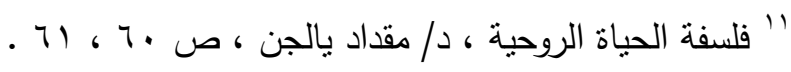


بذاته ودافع قوى إلى عمل تلك الخيرات ، لأن التقرب إلى الله عز وجل يكون من ناحيتين معا ، ناحية عبادة الله وناحية خدمه عبادة بعمل الخيرات لهم ، ومـع ذلك فإذا بحث كل واحد بمقتضى هذه الحياة الروحية من وسائل تقديم الخيرات والمشروعات المختلفة الخيرة فى حق الناس ، وسارعوا فى ذلك واستبقوا فيها ، فما من شك أن الحياة الاجتماعية والاقتصـادية تتقدم بسرعة مذهلة لأن هذه الروح تدفعهم إلى العمل فى الميادين المختلفة ، ليعملوا الخيرات الكثيرة (r'). ثالثاً : وقاية الإنسان من الأمراض التى تؤدى إلى إهمال الحياة الروحية . ويمكن تقسيمها إلى قسمين :

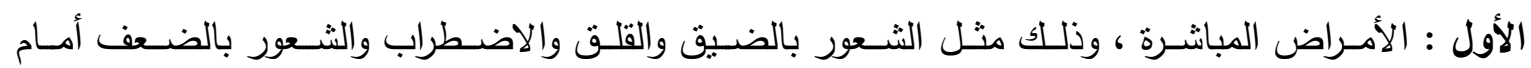
المسؤوليات ، والانهيار أمام المشكلات وقد ينتهى ذلك بالاتتحار ، وقد وجدنا كثيراً من المنتحرين انتحروا لكثير من هذه الأسباب .

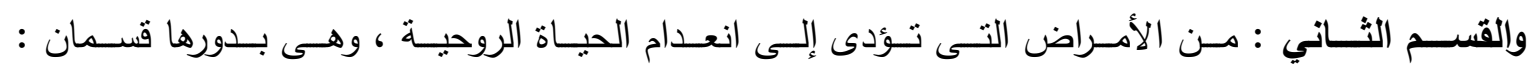
القسم الأول : الأمراض الجسمية التى تتأثر بالحالات النفسية المرضية السابقة . والثـاني : الجـرائم التـى يرتكبهـا والرذائـل الأخلاقيـة الذين انعدمت عندهم الحيـاة الروحيـة ثـم تـؤدى هذهـ

$$
\begin{aligned}
& \text { الامراض الأخلاقية إلى الأمراض الجسمية ('ا") . } \\
& \text { ثانياً : معنى التصوف : }
\end{aligned}
$$

لقد تعددت الآراء والأقوال فى معنى التصوف إلى أقوال ومعانٍ شتى ، منها ما قاله أبو محمد الحريري عن التصوف بأنه : " الاخول فى كل خلق سنى والخروج من كل خلق دني " ("') . وقال معروف الكرخي : " التصوف الأخذ بالحقائق واليأس مما فى أيدى الخلائق " . وقال الكتاني : " التصوف خلق فمن زاد عليك فى الخلق زاد عليك فى الصفاء " ( (10) .

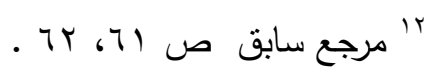

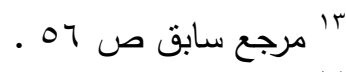

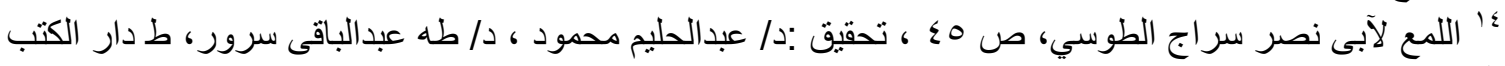


ويتحدث الثبلي عن التصـوف فيقول : زهد الصـوفي تحويل القلب مـن الأشياء إلى رب الأشبياء ،وليس الصوفي من استأنس بالذكر لكنه من استأنس بالمذكور ، ووفاء الصوفي هو الإخلاص بالنطق واستغراق

السرائر بالصدق ، وأما قلوب أهل الحق فإنها طائرة إلبه بأجنحة المعرفة ومستبشرة بمولاة المحبة ("') . وسئل عبدالواحد بن يزيد : " من الصوفية عندك ؟ قال : القائمون بعقولهم على فهم السنة ، والعاكفون عليها

بقلوبهم ، والمعتصمون بسيدهم من شر نفوسهم ( (lv).

وقال أبو عثمان المغربي : " التصوف قطع العلائق ، وفض الخلائق واتصال الحقائق " (1') . المبحث الأول : أثر التصوف على الجانب الروحي فحى حياة النبي صلى الله علبه وسلم. لقد كان رسول الله صلى الله عليه وسلم إمامـاً للمسلمين فى دينهم ودنياهم ، وضرب المثل الأعلى والقدوة الحسنة فى الزهد والعبادة ، والنسك والتقتف تطبيقاً لمنهج الإسـلام الذى رسمه المولى سبحانه وتعالى فى

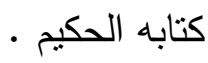
ولما كانت طبيعة البحث لا تستطيع استيفاء كل حياة الرسول صلى الله عليه وسلم فى هذا المجال فإنني سأكتفى ببعض الأقوال والأحوال التى تعطينا صورة واضحة عن حياة الرسول صلى الله عليه وسلم الروحية ومنهجه فى هذه الحياة التى نحن بصددها فى هذه الدراسة ، وحسبنا أن ننظر فى حياة النبي صلى الله عليه وسلم التى كان يقضيها قبل البعثة متعبداً فى غار حراء ، وفيما كان يفعله صلى الله عليه وسلم من مجاهدة نفسـه وعزلـة عن النـاس ، وأن نقارن بين هذه الحياة وبين حياة الزهاد والعباد والصـوفية ، ليتبين لنا مدى التوافق والثبه بين الحياتين ، ونتأكد من أن تعبد النبي صلى الله عليه وسلم فى غار حراء ، إنما هو البذرة الأولى التى نبتت منها الزهاد والعباد والصوفية ، وكان النبي صلى الله عليه وسلم يتحنث مرة كل عام كلما أقبل شهر رمضان ، يقيم طوال هذا الشهر مزودا بالقليل من الزاد ، متأملاً بقلبه فى كل ما امتلأ بـه الكون

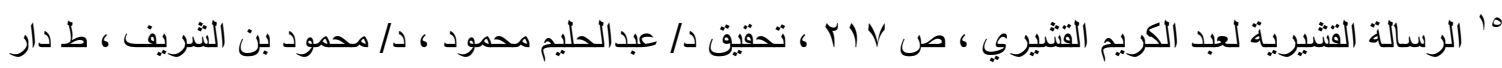

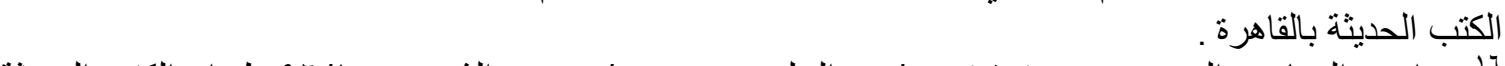
بالكوارف المعارف السهروردي ، تحقيق : د/ عبدالحليم محمود ، د/ محمود الثريف : /79 ط دار الكتب الحديثة

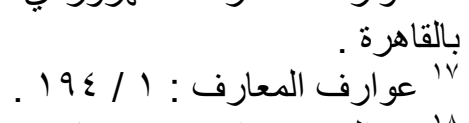

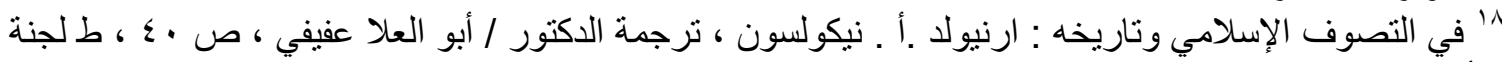

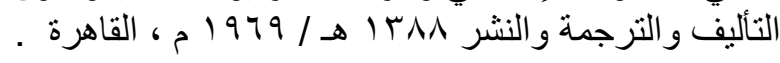


من آيات صنع الله ، فهناك كان يحيى صلى الله عليه وسلم حياة روحية خالصـة لا تشوبها شائبة من شوائب الحياة المادية ، ولا يفسدها شىء من متاع الدنيا وحطامها ، وظل النبي صلى الله عليه وسلم على هذا الحال متحنثاً ومتعبداً كلما عاوده شهر رمضان ، حتى صفت نفسه، وصقلت مرآة قلبه ، وتهيأ له أن يرى الرؤيا الصـادقة وإذ بأنوار الحقيقة تشرق فى أعماق نفسه ، وإذا هو يمعن فى الحق والخير واليقين ، حتى أنثرف على الأربعين ، وهنا قد أتيح لله من صفاء الروح ونقاء السريرة ما صسار معه أهلاً لأن يهبط عليه الملك الذى أخذ يضمه ويرسله مرة ومرة وفى كل مرة يأمره بأن يقرأ ، والنبي صلى الله عليه وسلم يجيبه ما أنـا بقارئ ، حتى أمره الملك أخيراً أن يقرأ باسم ربه الذى خلق وكانت قراءته صلى الله عليه وسلم فاتحة عهد جديد فى حياته الروحية (19) . (19) فهذه الحياة التى كانت يحياها النبي صلى اله عليه وسلم والتي كانت طريقاً إلى هبوط الملك عليه ، وسبيل قلبه على إثراق نور الوحى عليه ، وإذا نظرنا وتأمنا فى هذه الحياة وما انطوت عليها ، وقارنا بينها وبين حياة الزهاد والعباد الذين ظهروا فى صدر الإسـلام ، لرأينا أن التصوف هو الاسم الجامع بين طوائف أولئك وهؤلاء وتعاليمهم وما يعمدون إليه من رياضيات ومجاهدات يرمون بها إلى تتقية النفس وتصفية القلب ، وما يصطنعون فى تهذيب النفوس من محاسبة ومراقبة ، وما ينتهون اليه بهذ هذا كله من الهام مشرق ، وما من شك فى أن النبي صلى الله عليه وسلم وجد بذور الحياة الروحية الصافية الأولى فى التحنث والتعبد فى غار حراء ، والذى كانت ثمرته هذا الوحى المتألق بآيات النبوة البينات ، الفياض بحقائق التوحيد ودقائق العرفان

وإذا نظرنا فى حياته صلى الله عليه وسلم بعد البعثة وما كان يتصف صلى الله عليه وسلم من تقتف فى المأكل والملبس ومن عكوف على العبادة والتهجد ، حتى لقد نهاه الله عز وجل عن المبالغة فى ذلك بقوله \}

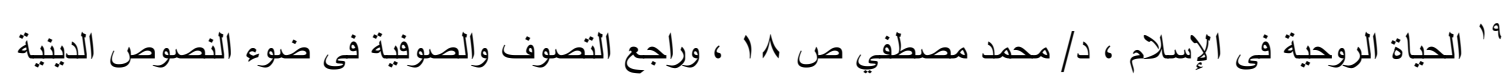

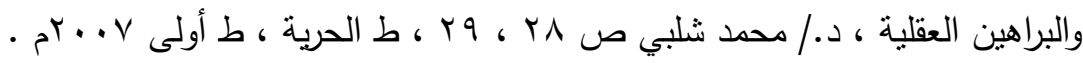

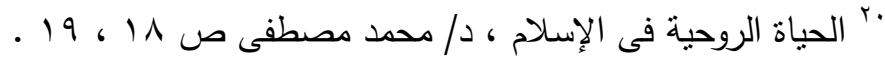




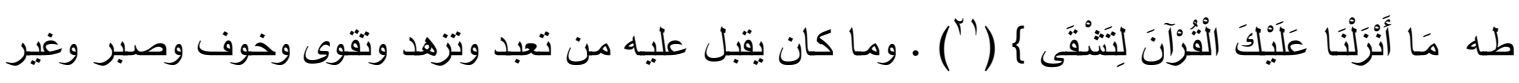
ذللك وما روى عنه من الأحاديث التى كانت منبعاً ومصدراً لما أخضع الصوفية أنفسهم له من رياضيات ومجاهدات ، وما كان يتقلبون فيه من المنازل والمقامات ، فلقد رويت عنه صلى الله عليه وسلم أقوالاً كثثرة رأى فيها الصوفية أنفسهم مستتداً لهم فى دعوى التصوف ، ونظراً لكثرة هذه الأحاديث والأحوال ، فإني سأقتصر على بعضها بحيث تعطينا صورة واضحة عن هذه الحياة ، وبخاصـة ما يتعلق منها بموقفه صلى الله عليه وسلم من الدنيا والمال والولد وكيف كان تعامله صلى الله عليه وسلم مع هذه الأمور فعن أبى أمامـه قال رسول الله صلى الله عليه وسلم \} عرض على ربى ليجعل لي بطحاء مكة ذهبا قلت لا يا رب ولكن أنثبع يوما وأجوع يوما فإذا جعت ضرعت إليك وذكرتك وإذا شبعت شكرتك وحمدتك \{ ( رضى الله عنه قال : دخلت على رسول الله صلى الله عليه وسلم وهو يصلى جالس فقلت : ما أصابك يا رسول الله : فقال الجوع ، فبكيت ، قال لا تبك يـا أبـا هريرة فإن شدة الجوع لا تصيب الجائع (يعنى يوم

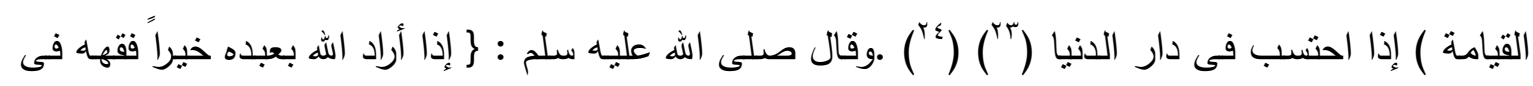
الدين وزهده فى الدنيا وبصره بعيوبه \{ ( ro وعنه (رضى الله عنه) قال : قال رسول الله صلى الله عليه وسلم : ( يؤتى بأنعم أهل الدنبا من أهل النار يوم القيامة ، فيصبغ فى النار صبغة ثم يقال : يا بن آدم هل رأيت خيراً قط ؟ هل مر بك نعيم قط ؟ فيقول

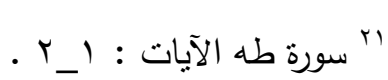

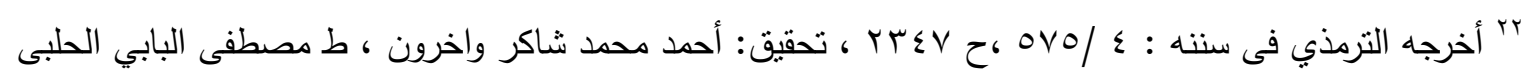

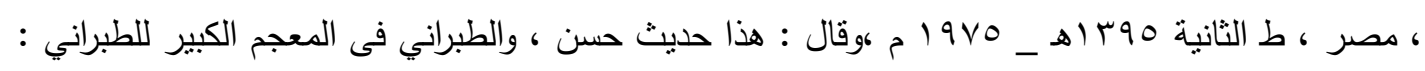

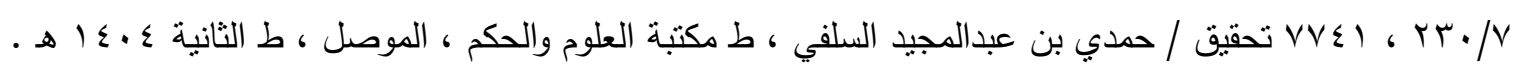

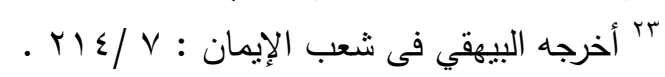

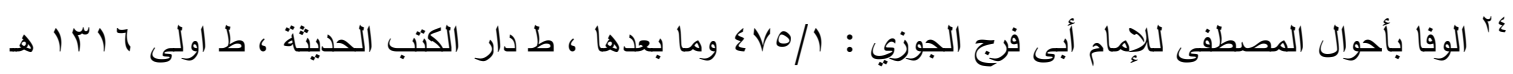

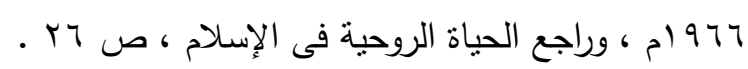

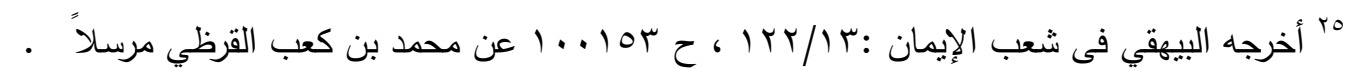


: لا واله يا رب • ويؤتى بأثند الناس بؤساً فى الدنيا من أهل الجنة ، فيقال له : يـا ابن ادم هل رأيت بؤساً

$$
\text { قط ؟ فيقول : لا والله ، ما مر بؤسا قط ولا رأيت شدة قط ) (") . }
$$

وعن أنس ابن ماللك رضى الله عنه عن النبي صلى الهه عليه وسلم أنه قال: (اللهم لا عيش إلا عيش الأخرة

، ماغفر للأنصار والمهاجرة ) (

وعن العباس سهل بن سعد الساعدي رضى الله عنه قال : جاء رجل إلى النبي صلى الله عليه وسلم فقال : يا رسول الله دلني على عمل إذا عملته أحبني الله ، وأحبني الناس ، فقال : ازهد فى الدنيا يحبك الله ، وازهد فيما عند الناس يحبك الناس ) ( ) فهذه الأحاديث تعطينا صورة عملية لحياة الرسول صلى الله عليه وسلم ، وكيف كان زاهداً فى هذه الحياة الدنيا ، فلم يكن مولعا بزخرفها وما فيها من متاع ومال ، وإنما كان بأخذ من هذه الدنيا بقدر ما يعينه ع الدين وطاعة الله عز وجل ففي كتب السنة صور كثيرة عن حياة التقتف والزهد التى كان عليها رسول الله صلى الله عليه وسلم ، فلقد كان صلى الله عليه وسلم يبيت الليالي العديدة جائعاً ما فى بطنه شىء ، بل إن أهله كانوا لا يجدون عشـاء ، وكان أغلب طعامهم الخبر الثـعير ، وفى هذا تقول السبدة عائشسة رضى الله عنها وأرضاها : ما شبع آل محمد منذ قدم المدينة من طعام بر ثناث ليال تباعاً حتى قبض ("rq ) . ومن كانت حياته هكذا لا يمكن أن يكون كانزاً لطعام ، لذا بروى الأمام مسلم أنه صلى الله عليه وسلم مات وما شبع من خبر زيت واحد مرتين ، ويقسم أبو هريرة على هذا فيقول : والذى نفس أبى هريرة بيده ما أثبع رسول الله صلى الله عليه وسلم أهله ثلاثة أيام تباعاً من خبز وحنطة حتى فارق الدنيا (·r) • بr صحيح مسلم : كتاب صفة القيامة والجنة والنار باب صبغ أنعم أهل الدنيا في النار وصبغ أشدهم بؤسا في الجنة

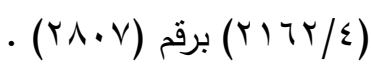

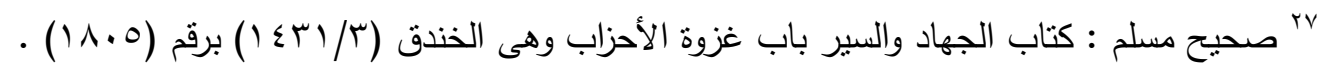

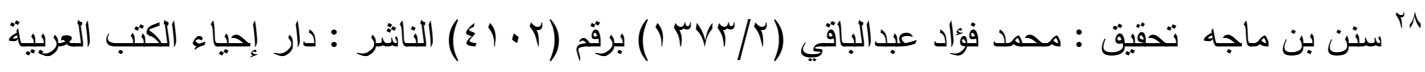

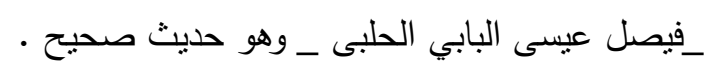

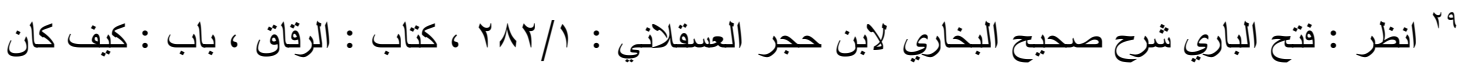

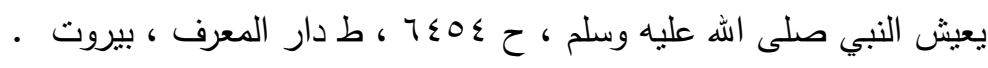

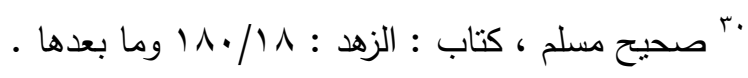


وإذا نظرنا إلى قناعته صلى الله عليه وسلم فى الملبس ، نجد أنه كان يلبس كتاناً أو صوفاً أو قميصـاً ، حيث يذكر المقدي فى كتابه صفوة التصوف أن النبي صلى الله عليه وسلم كان يلبس الصوف ، ولذا يقول أنس بن ماللك رضي الله عنه وأرضـاه : \} كان رسول الله صلى الله عليه وسلم يجيب دعوة العبد ، ويركب الحمار ، ويلبس الصوف \{ ("). وعن أبى بردة عن أبيـه قال : كلو شـاهدتا ونحن مع رسول الله صلى الله عليه وسلم وقد أصـابتتا السماء لحسبت ريحنا ريح الضأن من لبوسنا الصوف \{ (T) . وهكذا يمكن القول أن لبس الصوف الخشن الذى استعمله صوفيه المسلمين هو بلا شك تقليداً للرسول صلى الله عليه وسلم وصحابته ، وأنهم لم ينظروا إليه إلا على أنه لباس للنبي ، فلم يكن بهم الحاجة إلى تقليد لباس رهبان النصارى فى لباسهم ، بل كل فعله كان عن تقليد وتأسى بحضرة النبي صلى الله عليه وسلم

وحسبنا أن نثير هنا إلى ما كان يأخذ رسول الله صلى الله عليه وسلم من تهجد وعبادة واستخفار فقد روت السيدة عائشة رضى الله عنها وأرضاها " أن النبي صلى الله عليه وسلم كان يقوم الليالي حتى تتفطر قدماه ، فقلت له : لم تصنع هذا با رسول الله وقد غفر الله للك ما تقدم من ذنبك وما تأخر ؟ فقال : \{أفلا أكون عبدا

وعن أبسى هربـرة رضـى الله عنـه وأرضـاه قـال: سـعت رسـول الله صـلى الله عليـه وسـلم يقول : كواله إنـي لأستغفر الله وأتوب إلبه فى اليوم الواحد أكثر من سبعين مرة ج ( (ro) .

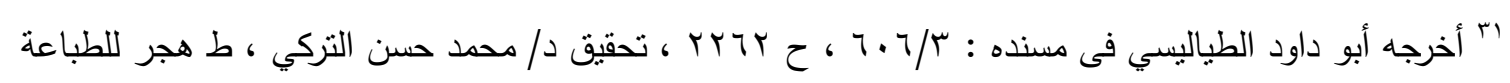

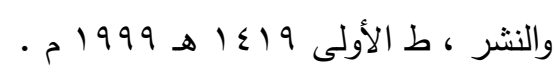

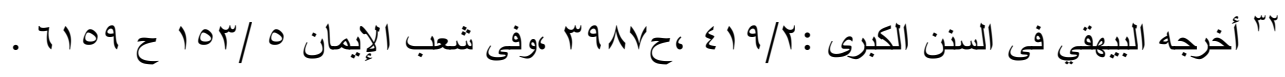

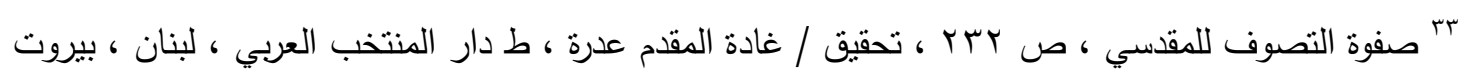
- 19906

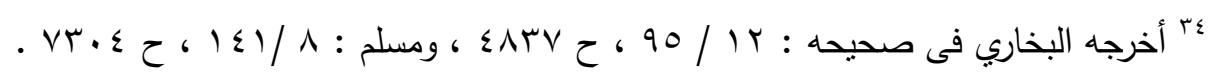

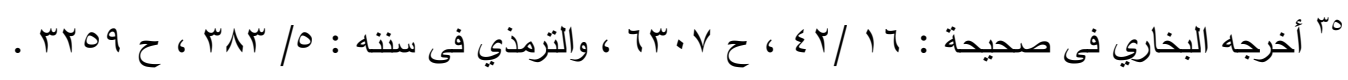


ويقول الدكتور / عبدالرحمن بدوى : بعدما أورد ثثلثة وعشرين حديثاً فى بـاب زهد النبي صلى الله عليه وسلم فى مأكله وملبسه وفى دنياه كلها ، وهذه الثواهد كلها كفيلة فى إثبات زهد النبي صلى الله عليه وسلم ، وانه كان يعيش عبشـة التقشف فى المأكل والملبس ، وقد استمر على ذلك حتى وفاته ، ولم يكن ذلك عن عدم قدرة فى الحصول على أطيب الطعام وأفخر الثياب لأن ما خص الرسول بالمعارك التى انتصر فيها المسلمون كان كافياً فى تحصيل ما يمكن لو أراد ، وإنما فعل ذلك عن مبدأ فى السلوك خليق وهو مبدأ

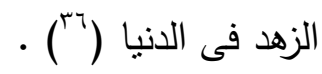
كذلك يقول الدكتور / محمد مصطفى حلمي : فكل أولئك دلائل حق وشواهد صدق على أن عبادة العباد وزهد الزهاد ، وتصوف الصوفية ، وما ينطوي عليه كله من المنازع الروحية والمعاني الخلقية ، قد وجد مادته الاولى فيما روى عن النبي صلى الله عليه وسلم من الأحوال ، وما أثز عنه من الأقوال (

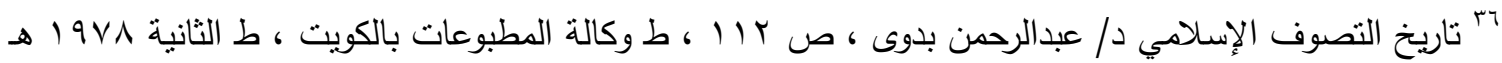

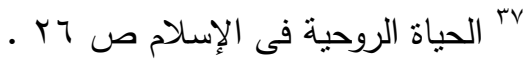


المبحث الثانى :أثر التصوف على الجانب الروحي فحى حياة الصحابة رضى الله عنهم أجمعين . حينما نتحدث عن أثر التصوف على الجانب الروحي فى حياة الصـابة فإننا نجد أن حياتهم كلها كانت منبعاً ومصدراً استقى منه الصوفية تصوفهم وحياتهم الروحية ، وذلك لأن حياة الصحابة كانت مليئة بالزهد والتقشف والإقبال على الله تعالى ، ولا يستطيع باحث أن يغفل ما انطوت عليه حياة الصحابة وأقوالهم من المنازع الروحية والأذواق القلبية . وحينما ننظر إلى حياة الصحابة رضى الله عنهم أجمعين نجد أنها كانت صورة من الحياة الروحية عند رسول الله صلى الله عليه وسلم ، لأنهم كانوا يقتدون بـالنبي صلى الله عليه وسلم فى كل شـى ، لذلك امتدحهم

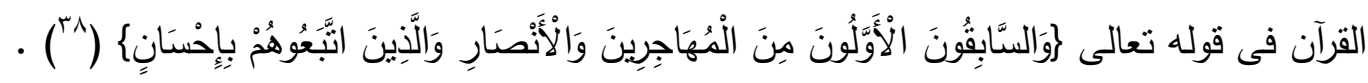

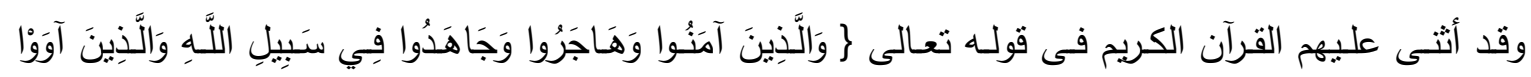

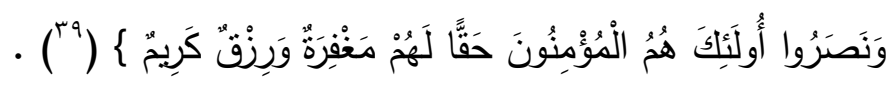
وقد بين لنا النبي صلى الله عليه وسلم مكانتهم علو منزلتهم فى أكثر من حديث فقال صلى الله عليه وسلم اله اله فى أصحابي لا تتخذوهم غرضـاً بعدى فمن أحبهم فبحبى أحبهم ومن أبغضهم فبيغضي أبغضهر ، ومن آذاهم فقد آذاني ، ومن آذاني فقد أذى الله ، ومن آذى الله يوشك أن يأخذه \{ (•) . وفى البخاري أن رسول اله صلى اله عليه وسلم قال : \} لا تسبوا أصحابي فلو أن أحدكم أنفق مثل أحد ذهباً ما بلغ مد أحدهم ولا نصبفه $\{$ ('). فهذه الآيات والأحاديث الشريفة تدل على فضل الصحابة ومكانتهم عند الله عز وجل وعند رسوله ، ولأجل هذا نظر الصوفية إلى الصحابة على أنهم قدوة لهم فى أقوالهم وأفعالهم وأحوالهم •

$$
\begin{aligned}
& \text { مبّرة التوبة الآية : . . 1 . }
\end{aligned}
$$

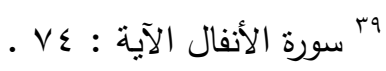

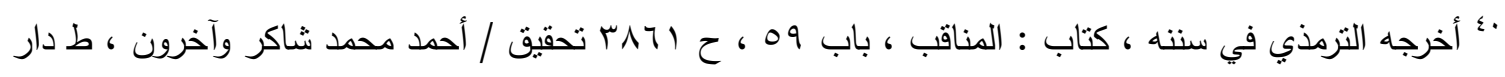

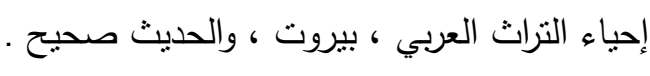

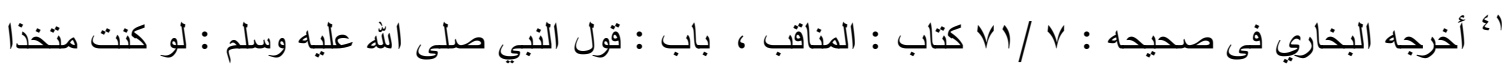

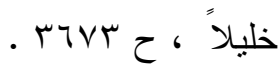


ومما روى عن أحوال الصحابة إجمالاً قول أبى عتبة الحلواني : ألا اخبركم عن حال كان عليها أصحاب رسول اله صلى الله عليه وسلم أولها : لقاء الله تعالى كان احب من الحياة ، والثانية : لا يخافون عدوا قلوا او كثروا ، والثالثة : لم يكونوا يخافون عذراً من الدنيا وكانوا واثقين برزق اله تعالى (rك) . ونبدأ بالحديث عن أصحاب رسول الهه صلى اله عليه وسلم بما بدأ بـه رسول اله صلى اله عليه وسلم حيث قال : \} اقتدوا بالذين من بعدى أبى بكر وعمر رضى الله عنهما \{ أثر التصوف على الجاتب الروحي فحى حباة وأحوال أبحى بكر رضى الله عنه وأرضاه ـ. لقد كان أبوبكر الصديق زاهداً حتى ليروي عنه أنه كان بطوى ستة أيام ولا يزيد عن ثوب واحد ، وكان يقول : إذا دخل العبد شىء العجب بثيء من زينة الدنيا مقته الله حتى يفارق تلك الزينة (؛؛) ، وكان يقول رضى

الله عنه وأرضاه : وجدنا الكرم فى التقوى ، والغنى فى اليقين ، والثرف فى التواضع ( (؛) . وكان يقول رضى الله عنه فى دعائه : \} اللهم امنحن الخير الوفير فى الدنيا ورغبني فى التخلص منها \{ فهو رضى الله عنه وأرضـاه بطلب خيراً وفيراً ، ثم يقف من هذا الخير موقف المتعفف عنه ، المنصرف عن الاشتغال به ، وهو بهذه الحالة يظهر معنى الزهد (1) . . وتحدث رضىى الله عنه وأرضاه عن المعرفة التى تتذوق الروح وأثرها فى الحياة الروحية لمن يتذوقها فقال: من ذاق من خالص المعرفة شيئًا شغله ذلك عما سوى الله ، واستوحش من جميع البشر (VV\&) . وعن زيد بن أرقم أن أبا بكر رضى الله عنه : استسقى فأتى بإناء فيه ماء وعسل ، فلما قربه من فيه بكى وأبكى من حوله ، فسكت وما سكتوا ، ثم عاد فبكى حتى ظنوا ألا يقدروا على مساءلته ، ثم مسح وجهه

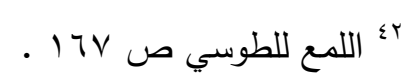

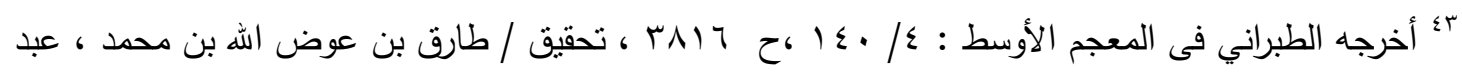

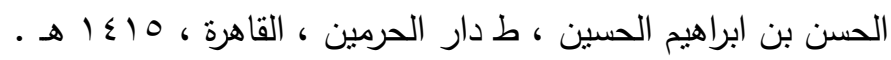

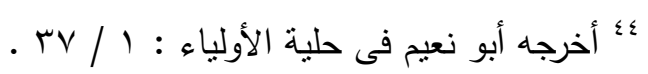

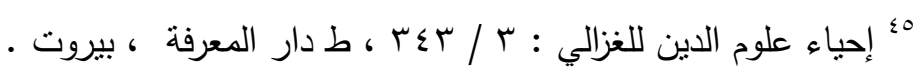

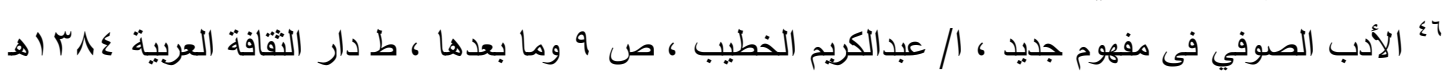

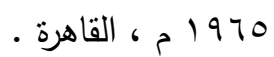

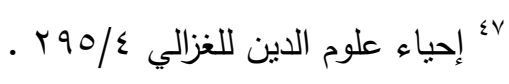


وأفاق • فقالوا : ما هاجك على هذا البكاء ؟ قال: كنت مع النبي صلى الله عليه وسلم وجعل يدفع عنه شيئاً ويقول : إليك عنى ، إليك عنى ، لم أر معه أحداً فقلت : يا رسول اله أراك تدفع عنك شئياً ولا أرى معك أحد ؟ قال : هذه الدنيا تمنلت فيها ، فقلت لها : إليك عنى فنتحت وقالت : أما والله لئن انفلت منى لا ينفلت من بعدك (^^) فخشيت أن تكون قد لحقتي فذلك الذى أبكاني قال الأصفهاني _رحمه الله _ وكان رضى الله عنه لا يفارق الجد ولا يجاوز الحد ، وقد قيل : إن التصـوف الجد فى السلوك إلى مالك الملوك (9؛ ) ،وكان رضى الله عنه وأرضاه يقول : وددت أن أكون خضراء تأكلني الدواب ، ولم أخلق مخافة العذاب وهول

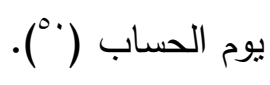

وعن زيد بن الأرقم ، قال : كان لأبى بكر الصديق رضى الله عنه مملوك يخل عليه فأتاه ليلة بطعام فتتاول منه لقمة ، فقال لله المملوك : ماللك كنت تسألني كل ليلة ولم تسألني الليلة ؟ قال: حملني على ذلك الجوع ، من أين جئت بهذا ؟ قال : مررت بقوم فى الجاهلية فرقيت لهم فوعدوني ، فما أن كان اليوم مررت بهم فإذا عرس لهم فأعطوني ، قال : إن كدت أن تهلكني ، فأدخل يده فى حلقه فجعل يتقيأ ، وجعلت لا تخرج ، فقيل له : إن هذا لا تخرج إلا بالماء فدعا بطست من ماء فجعل يشرب ويتقيأ حتى رمى بها ، فقيل لله : برحمك الله كل هذا من أجل هذه اللقمة ، قال : لو لم تخرج إلا مع نفسى لأخرجتها ، سمعت رسول الله صلى الله عليه وسلم يقول : كل جسد نبت من حرام فالنار أولى به (10) فخشيت أن ينبت شىء من جسدي من هذه اللقمة. قال الأصفهاني _ رحمه الله _ قد قيل : إن التصوف السكون إلى اللهيب ، فى الحنين إلى الحبيب

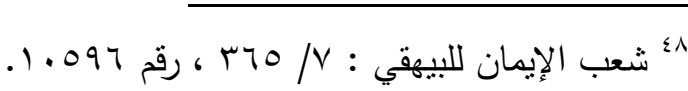

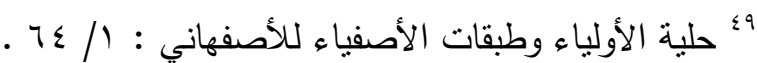

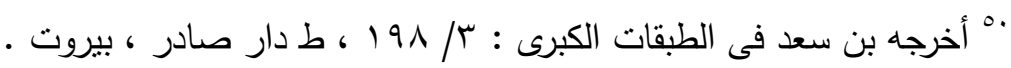

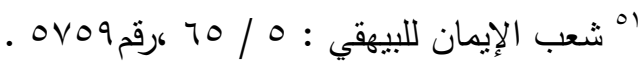

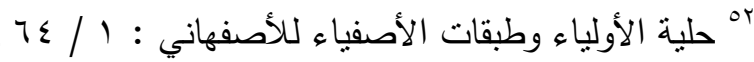


وهذه الرواية نسبت إلى سيدنا أبى بكر رضى اله عنه وأرضاه بعضـاً من الصفات الروحية التى منها الجوع ، والتقوى ، والزهد ، والورع ، وتحرى الحـلال ، وإرشـادات النبي صلى الله عليه وسلم وتعاليمهـ ونصـائحه ، وكل هذه الصفات تسمو بالنفس فتكون قريبة من ربها وعلى صلة قوية وعظيمة بمولاها وخالقها .

\section{عمر بن الخطاب رضى الله عنه وأرضاه .}

ثاني القوم عمر الفاروق ، أعلن الله بـه دعوة الصادق المصدوق ، محتملاً لما احتمل الرسول ، ومصطبراً على المكاره لمـا يؤمل من الوصـول ، ومفارقاً لمن اختار التتعيم والترفيـه ، وكان للحق قائلاً ، وبـالحق صائلاً ، وللأثقال حاملاً ، ولم يخف دون الله طائلاً ، وقد قيل : إن التصوف ركوب الصعب ، فى حلال

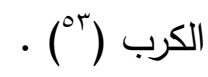

قال الثيخ الأصفهاني رحمه الهه : وكان عن فناء المـلاذ منتهياً ، ولباقي المعاد مبتغياً يـلازم المشقات ، ويفارق الثهوات ـ وقد قيل : أن التصوف حمل النفس على الثدائد الذى هو أنثرف الموارد (؛ْ) ، وكان رضى الله عنه وأرضـاه لا يجمع بين إدامين ، وقدمت إليه حفصـة رضى الله عنها مرقاً بارداً وصبت عليه زيتاً فقال : إدامان فى إناء واحد لا آكله حتى ألقى الله عز وجل (10) .

وقال الطوسي _رحمه الله_عن إقتداء الصوفية بعدر رضـى الله عنه وأرضـاه ما نصسه : لأهل الحقائق أسوة وتعلق بعهـر رضـى الله عنـه بمعـاني اختص بها مـن اختبـاره لبس المرقع أو الخشـونة وترك الثـهوات ، واجتتاب الثبهات ، وإظهار الكرامات وقلة المبالاة ، ومحق الباطل ومساواة الأقارب والأباعد فى الحقوق ، والتمسك بالأثند من الطاعات (") .

or حلية الأولياء وطبقات الأصفياء للأصفهاني : 1 / V V بتصرف .

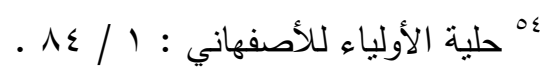

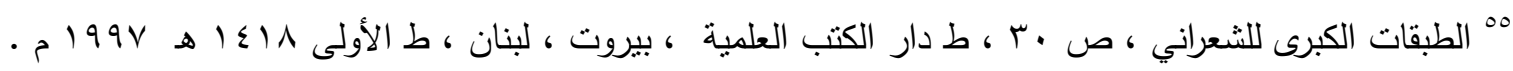

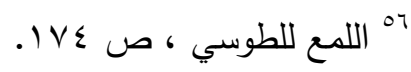


وكان رضى الله عنه من أزهد الناس فى الدنيا ورغبة فى الآخرة لذلك قال طلحة بن عبداله : ما كان عمر

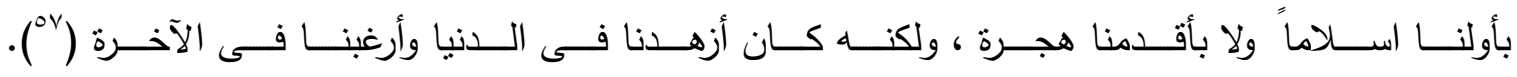
ومن مظاهر تزهد عمر وتمنل الحياة الروحية فيه ما ذكره أنس رضى الله عنه حين قال : تقرقر بطن عمر رضى الله عنه ، وكان يأكل الزيت عام الرمادة ، وكان قد حرم على نفسه السمن ، قال : فنقر بطنه بأصبعه وقال : تقرقر ما تقرقر إنه ليس للك عندنا حتى يحيا الناس (1ه) .

وليس هناك أدل على تقشف عمر من أنه كان يخطب وهو خليفة المسلمين وعليه إزار فيه ثتنا عشرة رقعة ، وقميص فيه أربع رقاع دون أن يكون له غبرهما ، وليس أدل من أنه كان يغسل ثثبه بيده ، ومن أثر الرضا والصبر فى النفس الخاضع لهما الآخذ بهما مما كتبه إلى أبى موسى الأشتري وهو يقول : أما بعد : فإن الخير كله فى الرضا ، فإن استطعت أن ترضى وإلا فاصبر • ومن قوله : وجدنا خير عيشنا الصبر ("09) . وعن الحسن أن عمر رضـى الله عنه قال : والله إن لو شئت لكنت من أطيبكم طعاماً ، وألينكم لباسـاً ،

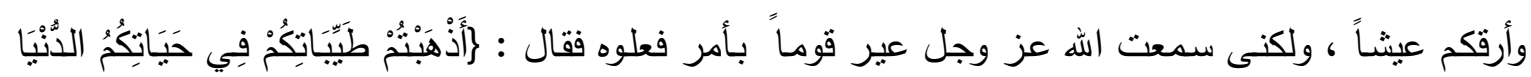

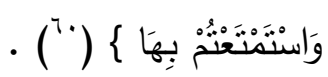
ويرى الصوفية أن ظهور الكرامات قد بلغت أعلى درجة على يد عمر ، ودلائل ذلك كما يقولون ظهرت لما كان يخطب فصاح فى وسط خطبته : يا سارية الجبل ، وسارية فى عسكر على باب نهاوند (") فسمع صوت عمر رضى الله عنه عندئذ ، وأخذ نحو الجبل وظفر بالعدو وقيل : لسارية كيف علمت ذلك ؟ فقال:

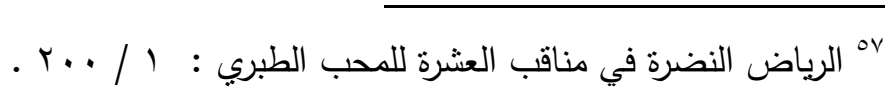

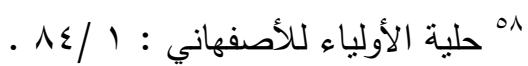

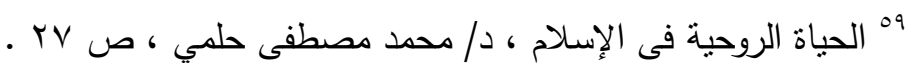

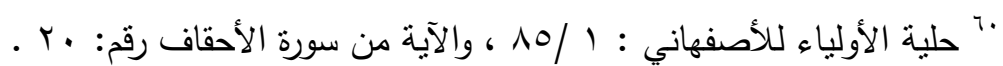

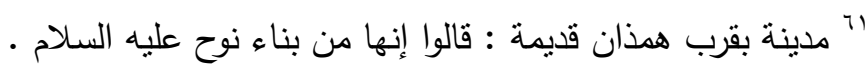

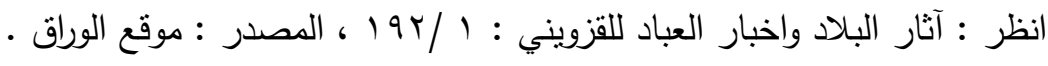




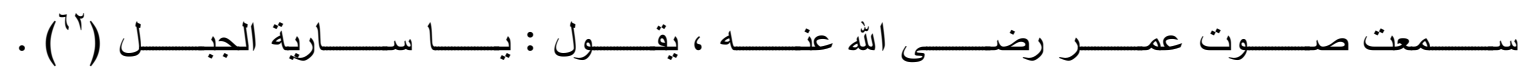
وقالت حفصة بنت عمر رضى اله عنه : يـا أمير المؤمنين لو لبست ثوباً هو أحسن من ثوبك ، وأكلت طعاماً هو أطيب من طعامك فقد وسع اله عز وجل من الرزق ، وأكثر من الخير ؟ فقال : إني سأخصمك كرك إلى نفسك ، ما تذكرين ما كان يلقى رسول الله صلى الله عليه وسلم من شدة العيش ، فما يذكرها حتى أبكاها ، فقال لها : واله إن قلت ذلك أما واله لئن استطعت لاشـاركنها بمثل عبشها الثديد ، لعلى أدرك معهما

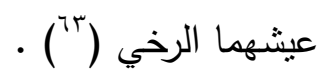

عثمان بن عفان رضى الله عنه وأرضاه.

لقد كان رضى الله عنه وأرضاه قدوة لأهل التصوف فى اكثر أموره وأحواله ، ففي مجاهداته لنفسه ، يروى عنه أنه حمل حزمة حطب من بعض بسانينه ، وكان له عدة مماليك ، فقيل له : لو دفعتها إلى بعض عبيدك ، فقال : إني قد استطعت ان أفعل ذلك ، فل ذلك على أنه كان لا يدع مجاهدة نفسه ("ج). وكان رضى اله عنه يتصف بالزهد التقتف ، ودائم التفكير فى اله ، والدأب على النظر فى كتاب الله بحيث كان يقضى نهاره طاوياً وليله محيياً وبحيث لم يكن يترك النظر فى المصحف كل يوم وهو يقول : هذا كتاب ربى ولا بد للعبد إذا جاءه كتاب سيده أن ينظر فيه كل يوم ليعمل بما فيه وما فتىء فى كذلك حتى قتل والمصحف بين يديه (10) ( )

وكان رضى اله عنه وأرضاه ممن هو قانت آناء الليل ساجداً وقائماً يحذر الآخرة ويرجو رحمة ربه ، غالب أحواله الحياء والكرم ، حظه من النهار الصيام والجود ، ومن الليل السجود والقيام ، وقد قيل : إن التصوف

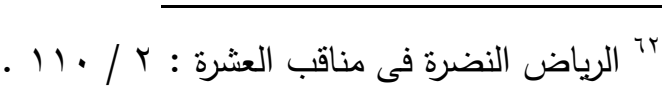

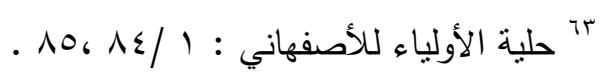

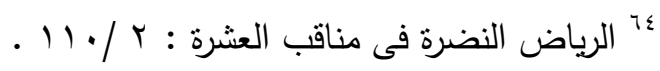

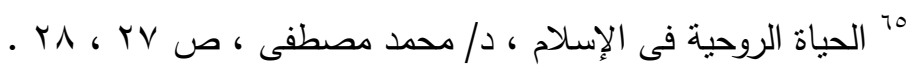


الإكباب على العمل ، تطرفاً إلى بلوغ الأمل (") ) ويروى عن زهده مع كثرة ماله أن الإنفاق كان أحب إليه من الإمساك فقد جهز جيش العسرة ، واشترى بئر رومة من يهودي كان يمنع المسلمين عنها ، حتى قال عنه رسول الله صلى الله عليه وسلم : ما ضر عثمان ما فعل بعد هذا ("آ" . وقد بين عثمان رضى الله عنه وأرضاه أن للمال وظيفة اجتماعية ، فقال : لولا أنى خشيت أن يكون فى

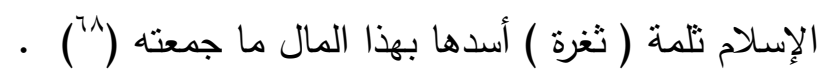

قال الثيخ الأصفهاني كان رضى اله عنه مبشراً بالمحن والبلوى ، ومحفوظاً فيها من الجزع والثكوى ، يتحرر من الجزع والصبر ، ويتبرر فى المحن بالثكر ـ وقد قيل : إن التصوف الصبر على مرارة البلوى ،

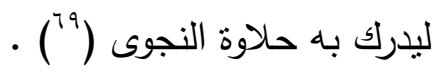

وعن أحمد بن سنان قال : سمعت عبدالرحمن بن مهدى يقول : كان لعثمان شيئان ليس لأبى بكر ولا عمر مثلكهما ، صبر على نفسـه حتى قتل مظلومـاً ، وجمـع النـاس على المصحف ، وكان بالمـال إرضـاء الله منوصلاً وببذله لعباده متتفلاً ، ولحظ نفسه منه متقلاً ، وقد قبل : إن التصوف ابتغاء الوسبلة إلى منتهى

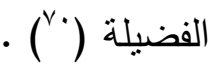

وقد تحدث صوفية الإسلام عن حادث مقتل سيدنا عثمان رضى الله عنه وارضاه فيقول الطوسي فى اللمع : ومما يدل على تخصيصه ، ولم يأنن لأحد بالقتال ، ولا وضع المصدف من حجره رضى الله عنه وأرضاه ،

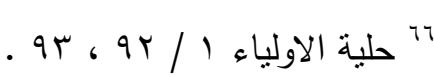

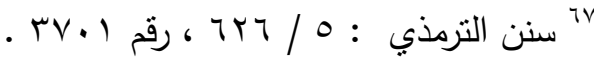

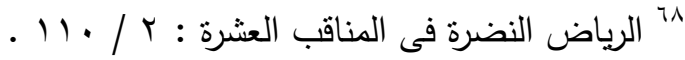

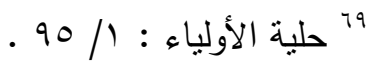

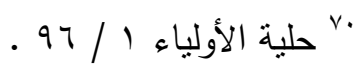




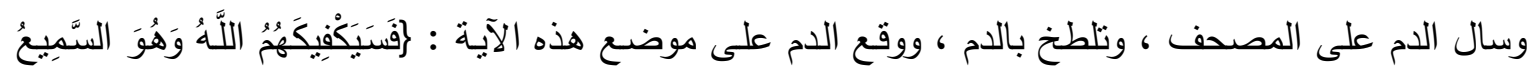
- الْعَليُمُ \{

وهكذا رأى الصوفية أن سيدنا عثمان بن عفان رضى اله عنه وأرضاه كان متحققاً بالوصول إلى الله وبمقام التمكين الذى جعله ثابتاً لمجاري الأقدار لا يزعزعه شىء مما حوله ـ وقد روى عنه أقوالاً لها دلالة صوفية ، منها قوله : وجدت الخير مجموعاً فى أربعة : أولها : النحبب إلى الله بالنوافل ، والثاني : الصبر على ردى الأحكام ، والثالث : الرضا بتقدير الله عز وجل ، والرابع : الحياء من نظر الله عز وجل ("vل) .

\section{على بن أبي طالب رضى الله عنه .}

عند الحديث عن حياة سيدنا على الروحية نجد أنه كان خشناً فى ملبسه ، بل إنه كان يوصى عماله وهو أمير المؤمنين على التبليخ فى هذه الحياة بما قل من العيش والرفق بالرعية ، وكثيراً ما كان يكتب إليهم يدعوهم إلى التقثف لأن هذا التقتثف هو طريق التنعم فى الآخرة ،وكان رضى الله عنه وأرضاه يأتي فى نهاية كل أسبوع إلى بيت المال فإن كان فيه مال قام بتوزيعه على الفقراء والمحتاجين دون ان يخص نفسه بشيء وكان يقول : يا صفراء يا بيضاء غرى غيرى حتى ما بقى دينار ولا درهم ( (V) . . وقد طلب سيدنا معاوية رضى الله عنه وأرضاه من أحد الناس أن يصف له على بن أبى طالب رضى الله عنه وأرضاه فكان ممن قاله : كان فينا كأحدنا ، يجيينا إذا دعوناه ، ويرضينا إذا سألناه ، لا يطمع القوى فى باطل عنده ، ولا ييأس الضعيف من حق يناله على يده ، كان يأنس بالله ووحشته ، وكان يبكى فى محرابه

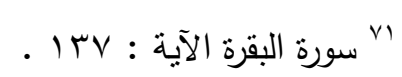

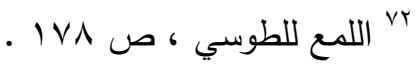

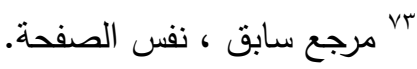

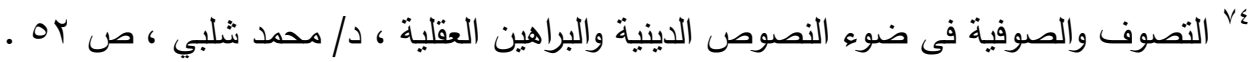


بكاء الحزين ويقول : يا دنيا غرى غيرى ، إلىً تعرضت أم إلىً تشوقت ، هيهات هيهات قد باينتك ثلاثاً لا رجعة فيها ، فنعيمك وعيشك قصير ، آه من قلة الزاد وطول السفر وحشة الطريق ( Vo ) . وكان رضى الله عنه وأرضاه صاحب القلب العقول ، واللسان السؤول ، والأذن الوعى ، والعهد الوافي ، فقاء عيون الفتن ، ووقى من فنون المحن ، فدفع الناكثين ، ووضع القاسطين ، ودمـ المارقين ، وقد قيل : إن التصوف مرامقة المودود ، ومصارمة المحدود (47) .

ولأمير المؤمنين على رضـى الله عنه وأرضـاه خصوصية خص بها من بين أصحاب رسول الله صلى الله عليه وسلم بمعاني جليلة ، وإثـارات لطيفة ، وخصـال شربفة تعلق بها أهل الصـوفية منها : لما سئل أمير المؤمنين رضى الله عنه وأرضاه وقيل له : بما عرفت ربك ؟ فقال : بما عرفني نفسه ، لا تشبهه صورة ، ولا يدرك بالحواس ، ولا يقال بالناس قريب فى بعده ، بعيد فى قربـه ، فوق كل شىء ولا يقال شىء تحته ، وتحت كل شىء ولا يقال شىء فوقه ، أمام كل شىء ولا يقال شىء أمامه ، داخل فى الأشياء لا كشيء ولا من شىء ، ولا فى شىء ، ولا بشيء ، سبحان من هو هكذا ولا هكذا غيره (

وكان من أقواله رضى الله عنه وأضـاه : ليس الخير أن يكثر مالك وولدك ، ولكن الخير أن يكثر علكك ، ويعظم حلك ، وأن تباهى الناس بعبادة ربك ، فإن أحسنت حمدت الله ، وإن أسأت استغفرت الله ، ولا خير فى الدنيا إلا لأحد رجلين ، رجل أذنب ذنباً فهو ندارك ذلك بتوبة ، أو رجل بسارع فى الخيرات ولا يقل عمل فى تقوى ، ولذلك قال الثيخ الأصفهاني _رحمـه الله _ وقد ذكر بعض ما نقل عنه من التقلل والتزهد ، واشتهر به من التزهب والتعبد ، وقد قيل : إن التصوف السمو عن الأعراض ، بالسمو إلى الأغراض (1^v) .

$$
\begin{aligned}
& \text { "مرجع سابق ، نفس الصفحة . }
\end{aligned}
$$

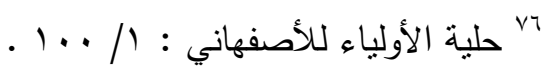

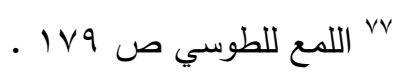

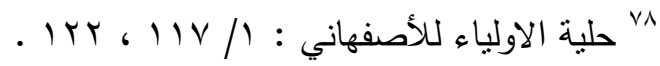


وروى عنه رضى الله عنه أنه قال : الخير كله مجموع فى أربعة : الصمت والنطق والنظر والحركة ، فكل نطق لا يكون فى ذكر الله تعالى فهو لغو ، وكل صمت لا يكون فى فكر فهو سهو ، وكل نظر لا يكون فى عبرة فهو غفلة ، وكل حركة لا تكون فى تعبد فهي فترة ، فرحم اله عبدا جعل نطقه ذكراً وصمته فكراً ونظره عبرة وحركته معبداً ، ويسلم الناس من لسانه ويده ( وعن على بن الأرقم عن أبيه ، قال : رأيت علياً وهو يبيع سيفاً له فى السوق ، ويقول : من يشترى منى هذا السيف فو الذي فلق الحبة لطالما كثف به الكرب عن رسول الله صلى الله عليه وسلم ، ولو كان عندي

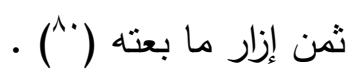

قال أبو عبيدة _رحمه الله _ : ارتحل الإمام على بن أبى طالب كرم الله وجهه وله تسع كلمات ، ثناث فى المناجاة ، وثلاث فى العلم ، وثلاث فى الأدب ، فأما التى فى المناجاة قوله : كفاني عزاً أن تكون لي رباً وكفى بي فخراً ان أكون للك عبداً أنت لي كما أحب فوفقني لما تحب ، واما التى فى العلم فهي قوله المرء مخبؤه تحت لسانه فتكلموا تعرفوا ، ما ضاع أمرؤ عرف قدره ، وأما التى فى الأدب فهي قوله أنعم على من شئت تكن أميره ، واستغن عمن شئت تكن نظيره ، واحتج إلى من شئت تكن أسيره (') . وقام رجل إلى على بن أبى طالب رضـى الله عنه وأرضـاه وسأله عن الإيمان ، فقال : الإيمان على أربع دعائم على الصبر ، واليقين ، والعدل ، والجهاد ، ثم وصف الصبر على عشر مقامـات ، وكذلك اليقين والعدل والجهاد ـ قال الطوسي _رحمه اله _ : إن صح ذلك فهو أول من نكلم فى الأحوال والمقامات (rr ) .

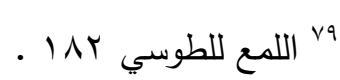

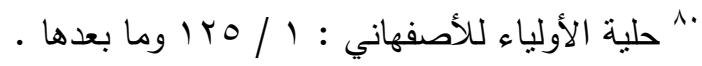

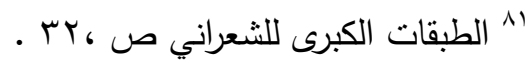

$$
\begin{aligned}
& \text { ז^ اللهع للطوسي ، ص .11 . . . }
\end{aligned}
$$


وقال رسول الله صلى الله عليه وسلم فى حقه : يا على إن الهه تعالى قد زينك بزينة لم تزين العباد بزينة أحب إلى الله منها ، هي زينة الأبرار عند الله تعالى الزهد فى الدنبا فجعلك لم لا تذرأ من الدنيا شيئاً ولا تذراً الدنيا منك شيئًا ، ووهب للك حب المساكين فجعلك ترضى بهم أتباعاً ويرضون بك إماماً (r) . .

لقد أسفرت دراستتا لهذا البحث عن نتائج ، وهذه النتائج هي :أولاً : إن علم التصوف يمثل الحياة الروحية فى الإسلام ، إذ أن بداية الحياة الروحية في الإسلام تبدأ من حياة الرسول صلى اله عليه وسلم وأصحابه وما كانوا يأخذون به أنفسهم من زهد في الدنيا واعراض عن زخرفها وجاهها وإقبال على الله بقلوبهم ، فالإسلام هو الذى أسس هذا العلم ومنه أخذت موضوعاته ، وعلى هذا فعلم التصوف ليس علماً جديداً في الإسلام ، وإنما هو أحد علومه الأصلية وجزء من الأجزاء التى يتألف منها التراث الديني والعقلي للإسـام .

ثانياً : إن الحياة الروحية التى كان يحياها النبي صلى الله عليه وسلم وأصحابه إذا حللناها إلى عناصرها التى تألفت منها ، ومعانيها التى انطوت عليها ، ووازنا بينها وبين الزهاد والعباد الذين ظهروا في صدر الإسلام من ناحية ، وبينها وبين حياة الصوفية الذين ظهروا بعد ذلك من ناحية أخرى ، رأينا أن التصوف هو الاسم الجامع لطوائف أولئك وهؤلاء وتعاليمهم ، وما يعدون إليه من رياضيات ومجاهدات يرمون بها إلى نتقية النفس وتصفية القلب . ثالثاً : أن علم التصوف مثل أب علم من العلوم ، فلم يبق على حالة واحدة فقط وإنما خضع للتطور والتأثير والتأثز ، فمصد التصوف عند أول تكوينه قد استمد اصوله من القرآن والسنة ، ومن أحوال الصحابة وأقوالهم ، وبهذا يكون المصدران الأساسيان للتصوف في الحقيقة هما القرآن والسنة ، وهذا ينتهى بنا إلى أن مذاهب الصوفية ترجع في أصلها إلى مصدر إسلامي ، إلا أنه بمرور الزمن وبحكم اتصال الأمم واحتكاك العقائد

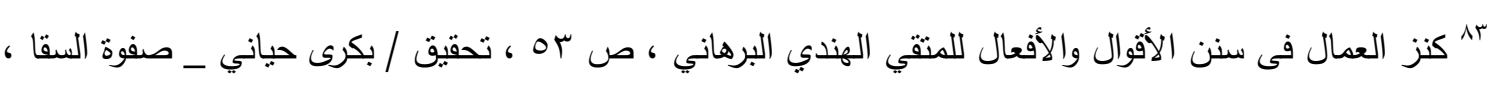

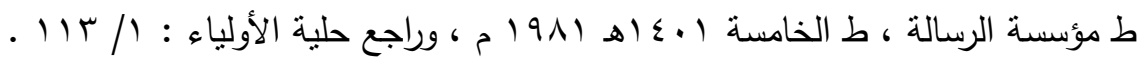


ظهر بعض المصطلحات التى لا تمت إلى التصوف بصلة ، وإنما هي مصطلحات دخيلة على التصوف ووليدة ثقافة غير إسلامية.

لرابعاً : إن التصوف ليس هروباً من الحياة كما يقول أعدائه ، وإنما هو محاولة من الإنسان للتسلح بقيم روحية جديدة تعينه على مواجهه الحياة المادية ، وتحقق له التوازن النفسي حيث يواجه مصاعبها ومشاكلها . خامساً : إن الحياة الروحية في الإسلام تجرى على سنن القصد الصالح في الحياة البشرية لا استغراق في مطالب الجسد ، ولا انقطاع عنه في سبيل الآخرة ، وإنما كانت قواماً بين هذا وذاك . المصادر والمراجع : (المصج _ القرآن الكريم _ جل من أنزله . ب _ كتب السنة المطهرة . r_ نظرات حول الإعداد الروحي الثهيد الثيخ حسن معن ، بدون • ع_ دراسات في التصوف والأخلاق ، د./ إبراهيم محمد إبراهيم ، بدون • _ التربية لعالم حائر ، سير رينتر لفجستون ، ترجمة / وديع الضبع •

ج_ شعب الإيمان للبيهقي : تحقيق : محمد سعيد بسيوني زغلول ، ط : دار الكتب العلمية ، بيروت ، ط

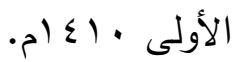

V_ الوفاء بأحوال المصطفى للإمام أبى فرج الجوزي ، ط دار الكتب الحديثة ، ط أولى 7 اس اهـ/ 979 ام . ^_ الرياض النضرة في مناقب العشرة للمحب الطبري ، ط القاهرة VY أهـ ـ

9 كنز العمال في سنن الأقوال والأفعال للمتقي الهندي البرهاني ، تحقيق / بكرى حياني ، صفوة السقا ، ط

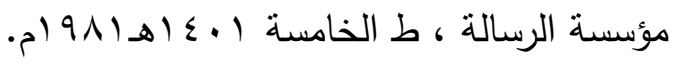
• ـ ـ تلبيس إبليس لابن الجوزي ، ط دار الجبل ، بيروت . 
1'_ المعجم الأوسط للطبراني ، تحقيق / طارق بن عوض الله بن محمد ، عبدالمحسن بن إبراهيم الحسيني

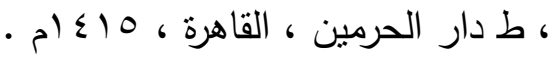

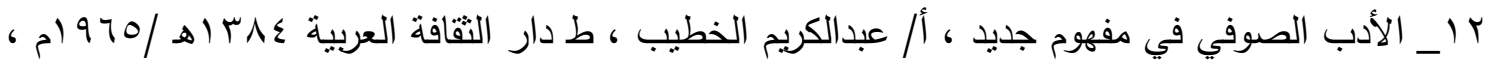
القاهرة .

ץ ـ _ صفوة التصوف للمقدسي ، تحقيق / غادة المقدم عدرة ، ط دار المنتخب العربي ، لبنان ، بيروت ، - 1990 ـ ا_ فتح الباري في شرح صحيح البخاري _ لابن حجر العقلاني _ طبعة دار الريان للتراث .

10_اللمع لأبى نصر سراج الطوسي _ حققه وقدم له د د/ عبدالحليم محمود ، وطه عبدالباقي سرور _ طبع

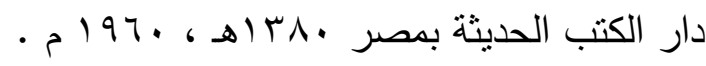

7 ـ ـ مدخل إلى التصوف الإسلامي د / أبو الوفا التفتازاني _ طبع دار الثقافة للنشر والتوزيع ـ الطبعة

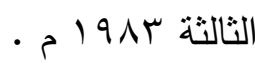

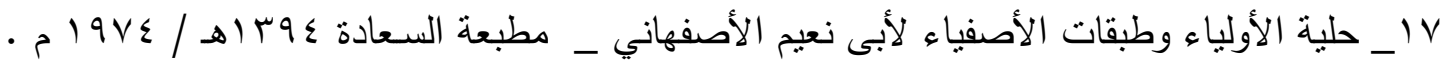

1 ـ التصوف والصوفية في ضوء النصوص الدينية والبراهين العقلية ، د./ محمد شلبي ، ط الحرية ، ط

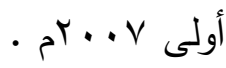

9 1 _ ناريخ التصوف في الإسلام ، د./قاسم عفيفي ، ترجمة / صادق نشأت ، ط مكتبة النهضة ، القاهرة

•r _ _ سنن ابن ماجه ، تحقيق / محمد فؤاد عبدالباقي ، ط دار إحياء الكتب العربية ، فيصل عيسى البابي - الحلبى

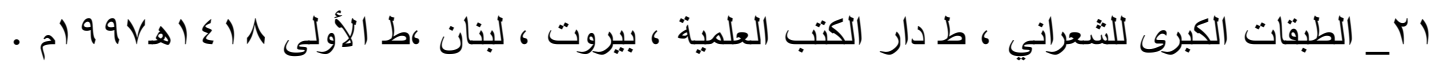
_r _ الطبقات الكبرى لابن سعد ، ط دار صادر ، بيروت . 


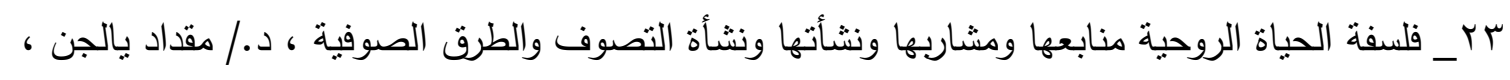

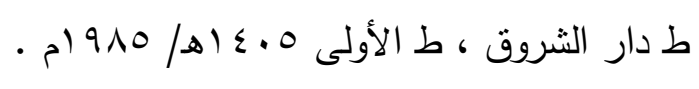

ع _ في التصوف الإسلامي وتاريخه ، ارنيولد .أ/ نيكولسون ، نرجمة د/ أبو العلا عفيفي ، ط لجنة التأليف

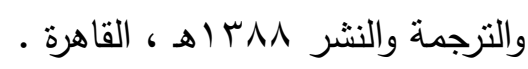

0ب_ مسند أبو داود الطياليسي ، تحقيق : د./ محمد حسن التركي ، ط هجر الطباعة والنشر، مصر، ط أه

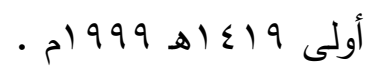

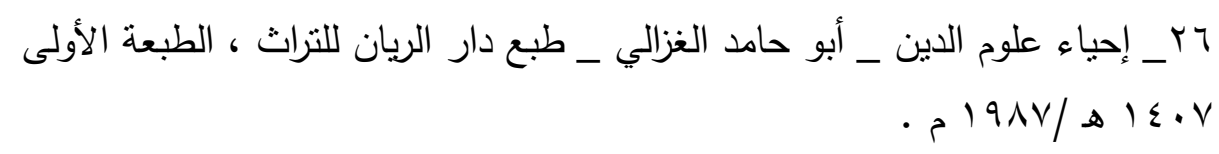

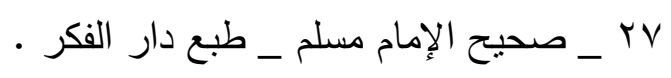

1 _ _ الحياة الروحية في الإسلام ، د/ مصطفى حلمي _ طبع الهيئة المصرية العامة للكتاب • 9Vام •

qr_ الإمام التزمذي فى سننه : تحقيق: أحمد محمد شاكر واخرون ، ط مصطفى البابي الحلبى ، مصر ،

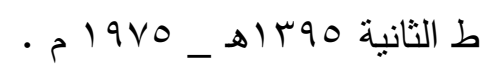

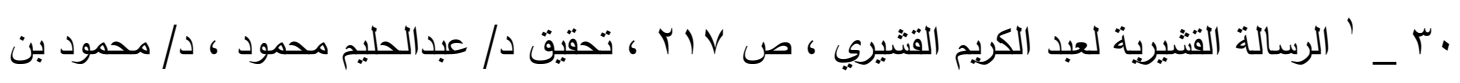

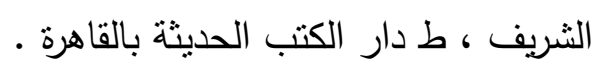

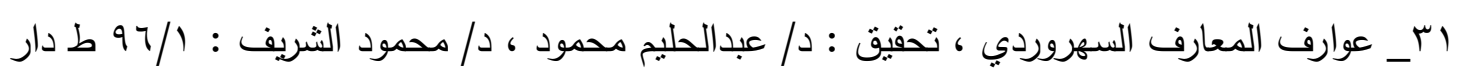

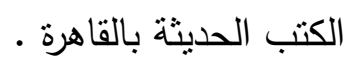

